\title{
Bank Stability: The Case of Nordic and Non-Nordic Banks in Latvia
}

\author{
R. Rupeika-Apoga ${ }^{1}$, S.H. Zaidi ${ }^{2}$, Y.E. Thalassinos ${ }^{3}$, E.I. Thalassinos ${ }^{4}$
}

\begin{abstract}
:
The banking industry is facing huge challenges due to technology-enabled innovation, to changes in customer preferences, to bank de-risking and to new regulatory initiatives. To go through all these changes, banks need to be stable.

The present study contributes to the empirical literature by identifying the determinants of stability of banks in the Latvian Banking Industry. This study covers both bank-specific (endogenous) factors and macroeconomic (exogenous) factors that impact the stability of banks. The data set used in this study is the annual financial statements of Latvian banks operated in the period 2003-2016.

Using multivariate regression analysis techniques, we found evidence that credit risk and efficiency ratio have a significant negative impact on banks' stability, whereas size of the bank, liquidity ratio, profitability, inflation and GDP growth have significant positive impact on bank's stability. We made comparison of bank-specific variables performance for Nordicowned and non-Nordic-owned banks.

Credit and liquidity risks, as well as efficiency ratio for Nordic-owned banks during the research period were higher, whereas size of the banks and profitability were better. Comparing measurement results of stability of banks, we received that Nordic-owned banks performance between 2003 to 2016 was better than non-Nordic-owned banks performance.
\end{abstract}

Keywords: Bank's stability, credit risk, liquidity risk, Z-Score.

JEL code: G01, G21.

\footnotetext{
${ }^{1}$ University of Latvia, Latvia, rr@ul.lt

${ }^{2}$ Capital University of Science and Technology, Pakistan

${ }^{3}$ Ph.D., Investmnt Manager M.A. Kharafi \& Sons, Kuwait City, jthalassinos@gmail.com

${ }^{4}$ University of Piraeus, thalassinos@ersj.eu
} 


\section{Introduction}

The first local banking crisis in 1995 had shown that local financial resources are not enough, and for the sector development the inflows of foreign investments are vital. And it was precisely here that the interests of both parties - Latvian commercial banks and foreign investors - coincided. Latvian banks were looking for cheap money for development, foreign capital saw the opportunity to make good money. Year 1995 heralded the beginning of a new era in Latvian banking sector: some foreign banks opened their branches (as Societe Generale, Vereinsbank), whereas some became shareholders of Latvian banks (Latvijas Investiciju banka, Unibanka, Hansabank-Latvija, Saules banka, Baltijas Tranzitu banka).

Nordic countries stated showing an active interest in Latvian banking sector at the same time, for instance, in 1996 Swedfund International AB bought some shares of Latvijas Unibanka, and in 2000 the Swedish bank Skandinaviska Enskilda Banken (SEB) increased its share in the joint-stock company (JSC) Latvijas Unibanka, the country's second largest bank, from 50.5\% to nearly 100\%. In 1995, Swedbank also started operating in Latvia under the name Hansabanka. In 2004 Maras banka was sold to Finish Sampo Bank. The entry of strategic foreign investors into major Latvian banks has made the sector more resilient to external shocks. If at the end of 1994, non-residents owned 25,3\% of banks' paid-up share capital in Latvia, then at the end of 2001, non-residents owned already $67,8 \%$ and in $2017-80.9 \%$. Within the first five years, foreign capital came to the banking sector mainly from Scandinavian countries and Germany.

Figure 1. Shareholder structure of banks by country from 2005 to 2017 in Latvia, \% (FCMC)

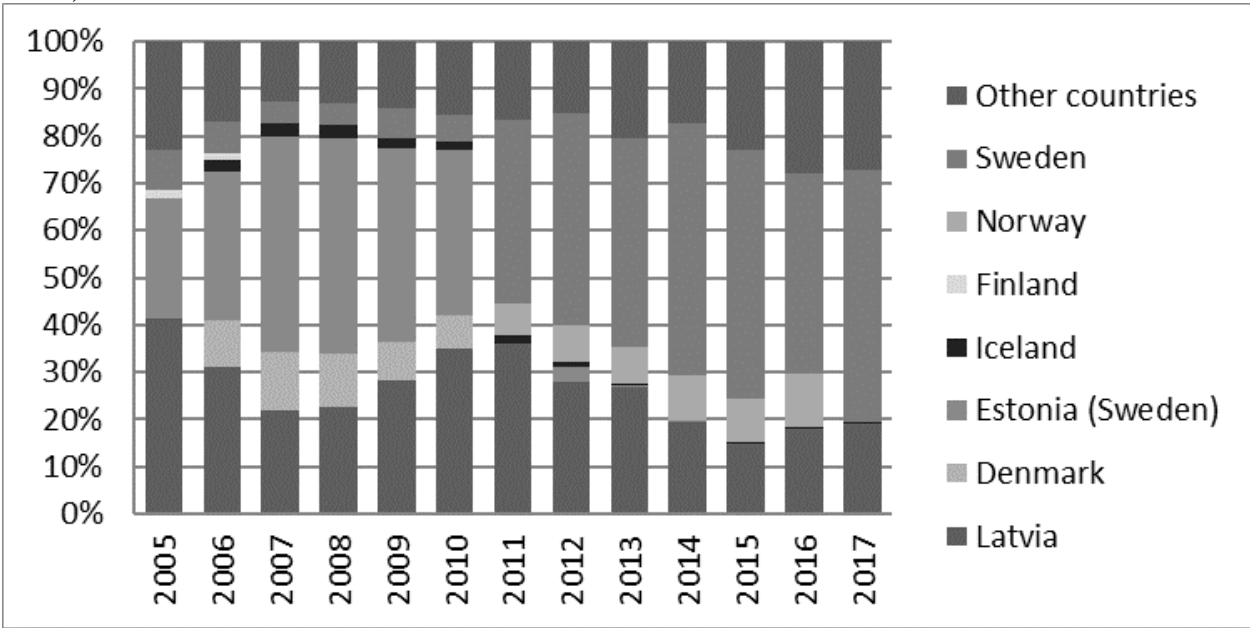

Source: Authors' calculations based on FCMC data. 
As can be seen from figure1. Nordic capital is dominating in Latvian banking sector. Starting from 1995 all Nordic countries have been present in Latvian market, but Swedish banks play the main role. In reality the presence of Nordic banks is even higher, as several branches of Nordic banks are operating in Latvia as well. The most important branches, that offer very broad services to Latvian residents are Danske Bank A/S Latvia branch and Nordea Bank AB Latvia branch (till 01.10.17), both with Nordic capital. At the end of 2016 Nordea Bank AB Latvia branch assets consisted of 3,2 mlr. euro, making it the fifth biggest bank in Latvia by assets, Danske Bank A/S Latvia branch had $331 \mathrm{mln}$. euro. Nordic-owned banks and branches all together at the end of 2016 made $50 \%$ of total banking assets. After the first local crisis, banks became far more conservative about extending loans, and there were far fewer instances of lending to persons connected with the bank (Rupeika-Apoga.R. and Danovi A., 2015).

The Latvian banking system consists of many commercial banks for such a small economy as Latvia, according to Financial Capital Market Commission (FCMC) at the end of 2017 the number of commercial banks was 16 and 5 foreign banks branches. Nordic banks are strongly represented on the Latvian market, holding 54\% of the total paid authorized capital of the banks at the end of 2017. Local capital owns $19 \%$ with the rest mostly held by banks from EU member-states, US and CIS countries. Nordic-owned banks in Latvia provide retail banking services to clients of any income level and mostly to Latvian residents, while locally owned banks and other foreign-owned banks specialize mostly in providing services to high-income clients and non-residents, mostly from Russia, Ukraine and other CIS states. Both sectors are large enough, Nordic banks assets share in total bank assets was $52 \%$ at the end of 2017 .

In Latvia, there is a unique situation when a large number of non-residents from the former Soviet Union republics use Latvian banking system, which is not observed in Estonia or Lithuania. At the end of 2017 non-residents have deposited 8,05 billion EUR in Latvian banks (40\% into total bank deposits), this amount of deposits has shrunk significantly within the last 2 years due to AML process. For instance, in 2015 the share of non-residents deposits was 56\% and was larger than the deposits of local companies, mainly deposits by citizens of Russia and other CIS states. CIS banks use Latvia as a bridge for carrying out activities in EU.

This study empirically investigates the determinants of bank stability in Latvian banking industry. Latvia is an open economy; thus, its financial institutions are relatively more exposed to external factors. In order to address the objective of the study both bank-specific and macroeconomic factors are included in the analysis. Bank size, profitability, credit risk, liquidity risk and efficiency of bank operations are studied as bank specific variables, whereas annual GDP growth rate and annual inflation rate are included as macroeconomic variables. 
The findings of this study will provide useful insights for regulators, practitioners, policy makers and researchers, but what is even more important to general society. The main contribution is the analysis of bank stability which is the major concern of the regulators in their pursuit of economic development. The banks' stability models of the large European economies are significantly different from small European economies. The banks in Latvia operate in a different regulatory \& legal environment and have unique institutional and market infrastructure as compared to other European banks which are analysed in the foreign literature for bank stability. There is considerable research in the area of Latvian banking industry, however the previous literature investigated different aspects including bank profitability, stability, competition, and banking crisis in different perspective.

There is a considerable gap in this area given the underlying foundation for this study. This study focuses on finding the factors that determine bank stability for Latvian banks by incorporating a sample period from 2003-2016. Therefore, this study is a temporal and contextual extension in the art of science. The second contribution of this study is to analyse the factors which determine stability of Latvian banking sector. For policy makers and bank management it will be useful to control those factors that can destabilize the banking system. And finally, to general society, to help them to choose the safe and stable banks.

The remaining paper is organized as follows: Section II consists of literature review and findings of different studies which are conducted on bank stability across the world. In Section III methodological approach, sample, data collection and research model are discussed. Empirical findings of the study are presented in Section IV. Section $\mathrm{V}$ is comprised of conclusion and recommendations.

\section{Literature Review}

A sizeable literature on identifying the indicators of bank stability has been developed in the past decade. In several studies the researchers have attempted to investigate the factors which can be restrained for a sustainable bank stability. Many empirical studies consider macroeconomic and bank specific factors as a precursor for bank stability. Claire (2004), for instance, explores the macroeconomic determinants of bank stability for the local banks of Singapore. Multiple regression analysis suggests that unemployment rate, exchange rate, aggregate demand and interest rate have significant impact on bank stability.

The same results are supported by Shijaku (2016) for the Albanian banking system. Principal component approach and simple average are applied to analyse the impact of bank specific, market specific and macroeconomic indicators on the stability of 16 banks of Albania for a period of 2008-2015. Results suggest that bank specific and macroeconomic factors are found to effect bank stability in a more consistent manner as compared to market specific factors. Likewise, Madi (2016) examines the relationship of a set of micro-economic and macro-economic variables with bank 
stability. The OLS technique is used for analysis to compare two separate periods i.e. pre-crisis 2005-2007 and during crisis 2008-2010 for UK Plc banks. The researcher finds different magnitude and direction of impact of the variables on banks' stability before and during crisis. Rupeika-Apoga and Nedovis (2014) stated that foreign exchange exposure in Latvia plays important role.

A few studies have examined risk management as an indicator of bank stability. Adusei (2015) for instance, investigates the impact of funding risk and bank size on bank stability for the rural banking industry in Ghana on quarterly data over the period of 2009-2013. Credit risk, liquidity risk, diversification in business model, profitability, GDP and inflation rate are included in analysis as controlled variables. Employing panel data analysis, the author concludes that bank size and funding risk have positive impact on bank stability.

Thus, bank stability can be increased by scaling up the operations of rural banking industry in Ghana. In the same manner, Buston (2016) investigates the net impact of active risk management on bank stability. Evidence from United States banks supports that banks with active risk management are relatively less exposed to instability during the period of financial crisis. On the other hand, Ghenimi et al. (2017) examine the main determinants of bank stability in 49 banks of Middle East and North African (MENA) region over the period 2006-2013. Credit risk and liquidity risk is selected as the determinants and Z-score is used as a measure of bank stability. Panel data analysis reveals that interaction of the two risks has significant and negative impact on bank stability.

Some researchers have developed frameworks which comprise of certain nonconventional variables as determinants of bank stability. For example, Nier (2005) studies whether disclosure of the information regarding banks' risk profile in annual reports has any impact on bank stability. A disclosure index is constructed including 17 categories of bank-specific risk factors to identify the relationship between transparency and bank stability. The author finds that banks with more transparency and information disclosure are more stable and are less likely to be confronted with financial crisis. On another note, Mirzaei et al. (2013) analyse the impact of market structure of bank on bank stability. Panel data analysis is used to study 23 emerging economies of Eastern Europe and Middle Eastern countries and 17 Western European countries from 1999-2008.

The findings suggest that more concentrated banking structure is more vulnerable to instability. On the other hand, Kisel Avoka and Kisel Ak (2013) analyse the indicators affecting bank stability by focusing on the banking industry of Slovakia for a span of ten years 2001-2010. Multiple regression analysis indicates that efficient management of liquidity and interest policy along with quality assets has positive impact on bank stability. Similarly, Kohler (2015) studies the impact of non- deposit funding and non-interest income on bank stability for $15 \mathrm{EU}$ countries for the period 2002-2011. Using Z-Score as a measure of bank stability, the results 
indicate that due to different business models across the countries, non-deposit funding and non-interest income has different effect on the bank stability for different countries. Titko et al. (2015) in a different perspective, study stabilitycompetition relationship for 16 Latvian commercial banks for the period 2007-2013. Multiple regression analysis is conducted to test the relationship between Z-score (measure of bank stability) and Lerner Index and Boone Indicator (measure of competition). The researchers found no evidence of the impact of competition on bank stability.

Evidence of comparative analysis are also found in the literature. In this vein, Diaconu and Oanea (2014) aim to identify whether there is difference in the determinants of bank stability for commercial vs cooperative banks. 14 Romanian banks are selected for analysis. GDP, inflation rate, interbank offering rate and financial market situation is regressed on Z-score. It was found that GDP and interbank offering rate have significant positive impact on bank stability for cooperative banks. The authors found no evidence of the significant relationship of any variable on bank stability for commercial banks.

Similarly, Karim (2016) performed a comparative analysis of 58 commercial banks, 5 Islamic banks and overall banking industry of Indonesia for a period 1999-2013. The effect of macroeconomic variables including GDP, interest rate and inflation rate on bank stability (Z-score) was investigated. It was found that there is a significant relationship between macroeconomic variables and bank stability for commercial banks and overall banking industry of Indonesia. Whereas for the Islamic banks, the researcher found no evidence of relationship between Z-score and macroeconomic variables. Similarly, Fang et al. (2014) discuss the relationship between institutional development and bank stability. The analysis is made on 434 commercial banks from 15 Eastern European countries. The examination of the impact of institutional reforms in the form of banking liberalization and corporate governance on banks stability is conducted for domestic vs foreign banks. The results reveal that domestic banks acquire more stability from institutional development than foreign banks.

In the following section, we attempt to find the behaviour of banking industry of Latvia with regards to the determinants of bank stability.

\section{Methodology}

The sample of the study is comprised of all commercial banks, except branches of foreign banks in the Republic of Latvia. Several branches of banks from EU Member States operate in Latvia, so at the end of 2016, there were seven such branches. As branches are not independent units, financial information about their activities in Latvia (balance sheets and Profit and Loss Statements) is not available and were not included in the research. Data span from 2003 till 2016. The number of banks due to mergers, acquisitions or exits from the market fluctuates from 16 to 
20. Mostly data were obtained from bank webpages, and for bankrupted banks data were obtained using Lursoft - the paid database for all registered legal entities subjected to Latvia's legislature and taxes. The data on bank-specific variables are collected from the banks' annual reports, whereas, the data on macroeconomic variables are extracted from the International Financial Statistics Database of IMF.

Data Analysis Technique: The study is conducted to investigate the determinants of bank stability in Latvia. As a prerequisite for data analysis, Augmented DickeyFuller Unit Root Test is applied to check the data stationarity of all the variables. The results reveal that all the variables are stationary at level. Thus, the series is random, and no pattern has been observed in data. In order to find the degree of association between dependent and independent variables Pearson Correlation Test is applied. Multivariate Regression Analysis technique is used to analyse the time series data set.

Econometric Model: The following econometric model is applied to accomplish the objectives of the study:

$\mathrm{Z}$-Score $=\mathrm{C}+\beta_{1} \mathrm{~S}+\beta_{2} \mathrm{P}+\beta_{3} \mathrm{LR}+\beta_{4} \mathrm{CR}+\beta_{5} \mathrm{ER}+\beta_{6} \mathrm{IR}+\beta_{7} \mathrm{GR}+\mu$,

where:

Z-Score is a measure of the bank stability

$\mathrm{S}$ is the size of the bank

$\mathrm{P}$ is the profitability of the bank

LR is the liquidity risk

$\mathrm{CR}$ is the credit risk

ER is the efficiency ratio

IR is the annual inflation rate

GR is the annual growth rate

$\mu$ is the random error term

Measurement of Bank Stability and its Determinants: Z-Score is considered as a standard measure of bank stability (Fang et al., 2014; Diaconu and Oanea, 2014; Adusei, 2015; Karim, 2016; Ghenimi et al., 2017). The bank stability is competed through the following equation:

$\mathrm{Z}-\mathrm{Score}=\frac{\mathrm{ROA}+(\mathrm{E} / \mathrm{A})}{\sigma \mathrm{ROA}}$

where:

ROA is the return on assets ratio of the bank

$\mathrm{E} / \mathrm{A}$ is the equity to assets ratio

$\sigma \mathrm{ROA}$ is the standard deviation of return on assets. 
Bank size is measured by taking natural log of the total assets of the bank (Amidu and Wolfe, 2013; Adusei, 2015). Profitability is computed through ROE (Return on Equity) as suggested by Mollah and Zaman (2015) and Ghenimi et al. (2017). The ratio of total loans to total assets is used as a measure of credit risk (Curak at al., 2012), whereas, ratio of costs to incomes is taken as a proxy of bank efficiency (Petria et al., 2015; Madi, 2016). Liquidity ratio is used as a proxy of liquidity risk (Nikolaou, 2009) and was taken from banks' annual reports. Annual inflation rate and annual GDP growth is included to measure the impact of macroeconomic variables on bank stability (Clair, 2004; Nier, 2005; Monnin and Jokipii, 2010; Kisel, 2013; Diaconu and Oanea, 2014). The last term $\mu$ denotes the random error term which follows a normal distribution with mean 0 .

\section{Results and Discussion}

The descriptive statistics have shown an average Z-Score of 2.2936 for Latvian banks. Z-score is the measure of distance of bank from the insolvency, thus higher value reveals higher bank stability.

Table 1. Descriptive Statistics

\begin{tabular}{|l|l|l|l|l|l|}
\hline & N & Minimum & Maximum & Mean & Std. Deviation \\
\hline Z-Score & 256 & -6 & 14 & 2,2939 & 3,237 \\
\hline Size & 256 & 16 & 23 & 20,06 & 1,413 \\
\hline Profitability & 255 & -8 & 1 & 0,08 & 0,563 \\
\hline Liquidity Risk & 257 & 0,1 & 74,74 & 1,63 & 6,030 \\
\hline Credit Risk & 253 & 0 & 1 & 0,43 & 0,261 \\
\hline Efficiency Ratio & 243 & 0 & 11 & 0,44 & 0,806 \\
\hline Inflation Rate & 14 & $-0,01$ & 0,15 & 0,04 & 0,041 \\
\hline GDP Growth & 14 & $-0,144$ & 0,119 & 0,04 & 0,066 \\
\hline
\end{tabular}

Descriptive statistics is used to identify the type of data. The variables are treated for the possible outliers resulted in difference in the sample size for different variables. $\mathrm{Z}$-Score is the measure of stability of a bank. For banks in Latvia we found Z-Score ranges from as low as $-5,83$ to as high as 1,21 . There is a considerable deviation in the selected banks in terms of profitability with a maximum negative profit of -8 to maximum profit of 1 . The size of banks in Latvia is 20,06 on average with a 
standard deviation of 1,413 . On average the efficiency ratio is 0,08 . Whereas the mean of credit risk is showing 0,43 risk on average with standard deviation of only 0,261 . On average inflation rate and GDP growth rate remain $4,236 \%$ and $4.06 \%$ respectively during the period of study.

Table 2. Pearson Correlation Analysis

\begin{tabular}{|c|c|c|c|c|c|c|c|c|}
\hline & $\begin{array}{l}\text { Z- } \\
\text { Score }\end{array}$ & Size & $\begin{array}{l}\text { Profitabi } \\
\text { lity }\end{array}$ & $\begin{array}{l}\text { Liquidity } \\
\text { Risk }\end{array}$ & $\begin{array}{l}\text { Credit } \\
\text { Risk }\end{array}$ & $\begin{array}{l}\text { Efficie } \\
\text { ncy } \\
\text { Ratio }\end{array}$ & $\begin{array}{l}\text { Inflation } \\
\text { Rate }\end{array}$ & $\begin{array}{l}\text { GDP } \\
\text { Growth }\end{array}$ \\
\hline $\begin{array}{l}\text { Z- } \\
\text { Score }\end{array}$ & 1.000 & & & & & & & \\
\hline Size & .093 & 1.000 & & & & & & \\
\hline $\begin{array}{l}\text { Profi } \\
\text { tabili } \\
\text { ty }\end{array}$ & .268 & .009 & 1.000 & & & & & \\
\hline $\begin{array}{l}\text { Liqui } \\
\text { dity } \\
\text { Risk }\end{array}$ & .100 & .068 & -.007 & 1.000 & & & & \\
\hline $\begin{array}{l}\text { Credi } \\
\text { t } \\
\text { Risk } \\
\end{array}$ & -.055 & .331 & -.214 & -.133 & 1.000 & & & \\
\hline $\begin{array}{l}\text { Effici } \\
\text { ency } \\
\text { Ratio }\end{array}$ & -.432 & .138 & -.162 & .012 & -.060 & 1.000 & & \\
\hline $\begin{array}{l}\text { Inflat } \\
\text { ion } \\
\text { Rate } \\
\end{array}$ & .275 & -.115 & .076 & -.067 & .189 & -.258 & 1.000 & \\
\hline $\begin{array}{l}\text { GDP } \\
\text { Gro } \\
\text { wth } \\
\end{array}$ & .414 & -.251 & .133 & -.024 & -.002 & -.639 & .249 & 1.000 \\
\hline
\end{tabular}

Correlation test is performed to identify the degree of association between dependent and independent variables. Size and profitability is found to have positive association with bank stability. Which implies that large and profitable banks are less exposed to instability. The analysis is also depicting a positive relationship between GDP growth, inflation rate and bank stability. Which supports the fact that a growing economy always provide a conducive environment for the development of a stable financial system.

We also find a positive association between banks stability and liquidity. The positive relationship between liquidity and bank stability is consistent with the previous studies that liquidity makes banks less vulnerable to shocks. Banks with more liquidity can meet any unexpected large withdrawals or utilisation of committed credit lines (Douglas and Rajan, 2005; Carletti et al., 2007). Credit risk is negatively associated with bank stability. Evidence from recent financial crisis has revealed that mostly those banks were failed which had confronted with the credit risk (Imbierowicz and Rauch, 2013). We find a negative relationship between banks 
stability and efficiency. The association is consistent with the study of Fell and Schinasi (2005) who allude to the fact that greater efficiency might be accompanied by higher levels of asset market volatility and of propensity to financial stress.

Table 3. Coefficients

\begin{tabular}{|c|c|c|c|}
\hline & Beta & $\mathbf{t}$ & Sig. \\
\hline (Constant) & -8.889 & -3.469 & .001 \\
\hline Size & .573 & 4.414 & .000 \\
\hline Profitability & .008 & 2.706 & .007 \\
\hline Liquidity Risk & .001 & 1.654 & .099 \\
\hline Credit Risk & -1.826 & -2.508 & .013 \\
\hline Efficiency Ratio & -.032 & -3.481 & .001 \\
\hline Inflation Rate & .157 & 3.646 & .000 \\
\hline GDP Growth & .127 & 3.755 & .000 \\
\hline \multicolumn{4}{|c|}{$\begin{array}{l}\text { Sig. }=.000 \\
\text { Independent variables: Size, Profitability, Credit Risk, Efficiency } \\
\text { Ratio, Inflation Rate, GDP Growth, Liquidity Ratio } \\
\text { Dependent variable: Bank Stability }\end{array}$} \\
\hline
\end{tabular}

The study is an investigation of the factors affecting bank's stability in Latvia. The findings from the research model are presented in Table 6 . The results reveal a positive and significant relationship between size and bank stability. This implies that large banks are more stable as compared to small banks. Large banks are less susceptible to financial fragility because they enjoy higher economies of scale and scope; therefore, they have the potential to diversify loan-portfolio risks efficiently and geographically through cross-border activities (Mirzaei, Moore and Liu 2013).

Profitability has shown a positive and significant relationship with bank stability implying that increasing profitability results in increasing stability. This is understandable because, all things being equal, increasing profits would mean more funds for the bank to meet contingencies. Since a profitable financial system absorbs negative shocks, profitability is central to the operation of commercial banks.

Credit risk is found to be negatively related with bank stability. The implication is that deteriorating lending standards portend dire consequences for the stability. These findings are consistent with the previous evidence from the financial crisis. The banks with substandard credit suffered the most during financial crisis. We also found a positive impact of liquidity on banks stability. This is because higher asset liquidity directly benefits stability by encouraging banks to reduce the risks on their balance sheets and by facilitating the liquidation of assets in a crisis. It also makes 
crises less costly for the banks. As a result, banks have an incentive to take on an amount of new risk that more than offsets the positive direct impact on stability. Efficiency is found to have a negative and significant impact on banks stability. One of the possible reasons is that greater efficiency might be accompanied by higher levels of asset market volatility and of propensity to financial stress.

We found a positive and significant relationship between inflation and bank stability. The findings are consistent with the view that when interest rates are adjusted according to the expected inflation, the inflation effect on the stability of the banks is positive. This is also in alignment with the postulation of Perry (1992) that inflation should positively affect bank stability when it is anticipated and factored into the pricing process.

GDP growth has shown a positive and significant effect on bank stability which reveals that an overall growth in economy acts has a buffering effect on the stability of financial system. It also supports the fact that a growing economy always provides a conducive environment for the development of a stable financial system. The value of $\mathrm{R}^{2}$ is $34.5 \%$ which indicates that about $35 \%$ variation in the dependent variable is explained by the independent variables. The value of F-statistic is 18.683 and is significant which shows that model is a good fit.

The Variance Inflation Factor is used as collinearity diagnostic. The VIF for all the independent variables is below 2.5 indicating that there is no multicollinearity problem in the data. Durbin Watson test statistics is used to detect the presence of autocorrelation at lag 1 in the residuals. The value of Durbin-Watson stat is 1.91 which shows that there is no problem of autocorrelation in the data.

\subsection{Nordic vs Non-Nordic banks}

\subsubsection{Size}

Table 4 presents Latvian banks with total assets in thousand euros in 2016.

Table 4. Total assets of Latvian banks in 2016, thousand euro (FCMC, 2016)

\begin{tabular}{|l|l|}
\hline Banks & $\begin{array}{l}\text { Total } \quad \text { assets, } \\
\text { thousand Eur }\end{array}$ \\
\hline Swedbank & $\mathbf{5 2 6 4 0 5 1}$ \\
\hline ABLV Bank & 3849585 \\
\hline SEB banka & $\mathbf{3 5 0 9} \mathbf{1 9 0}$ \\
\hline Rietumu Banka & 3465605 \\
\hline Citadele banka & 2629610 \\
\hline DNB banka & $\mathbf{2 1 1 4 3 6 5}$ \\
\hline NORVIK BANKA & 887401 \\
\hline Baltikums Bank AS & 651492 \\
\hline Reǵionālā investīciju banka & 501800 \\
\hline
\end{tabular}




\begin{tabular}{|l|l|} 
Rigensis Bank & 339659 \\
\hline Meridian Trade Bank & 311679 \\
\hline Baltic International Bank & 306751 \\
\hline PrivatBank & 304170 \\
\hline Expobank & 300368 \\
\hline Latvijas pasta banka & 205672 \\
\hline Bank M2M Europe & 177739 \\
\hline
\end{tabular}

As can be seen from Table 4, Nordic-owned banks are one of the biggest banks in Latvia by total assets, the share of 3 Nordic-owned banks is $44 \%$ of all total assets. This makes Nordic banks more stable comparing to local owned banks in general.

\subsubsection{Credit risk}

Median of credit risk proxy (Loan-To-Asset ratio) for Nordic banks was 78.15\%, whereas for non-Nordic banks it was only 35.28\% for the period 2003-2016. Such difference can be explained by different business models. Nordic-owned banks in Latvia provide universal services to clients of any income level and mostly to Latvian residents, at the same time these banks are the main loan market players in Latvian market, as their share at the end of 2016 was $68 \%$ of total loans and receivables. While local banks and other foreign-owned banks specialise mostly in providing services to high-income clients and non-residents, mostly from Russia, Ukraine and other CIS states, with market share in loan market only $32 \%$ at the end of 2016. From bank's stability point of view Nordic banks are more risky, as their loan portfolio is bigger comparing to non-Nordic banks.

\subsubsection{Liquidity risk}

Liquidity risk proxy (liquidity ratio), calculated as all assets with maturity up until 1 month to current liabilities with maturity up until 1 month, shows how well bank can meet its short-term obligations. The minimum requirement for liquidity ratio in Latvia is $30 \%$, but the total liquidity ratio of banking sector reached $61,9 \%$ by the end of December 2016. Additionally, to address risks stemming from providing services to non-resident customers, individual liquidity ratio depending on the proportion of a non-resident bank's assets funded by non-resident deposits, was introduced in March 2013 (see Table 5).

Table 5. Individual liquidity ratio from 2013 in Latvia, \% (OECD, 2016)

\begin{tabular}{|l|l|l|l|}
\hline $\begin{array}{l}\text { Non-resident deposits to } \\
\text { total assets ratio }\end{array}$ & $\begin{array}{l}\text { From 20\% up } \\
\text { to 40\% }\end{array}$ & $\begin{array}{l}\text { Greater than } \\
40 \% \text { up to 70\% }\end{array}$ & $\begin{array}{l}\text { Greater } \\
70 \%\end{array}$ \\
\hline Individual liquidity ratio & $40 \%$ & $50 \%$ & $60 \%$ \\
\hline
\end{tabular}

Median of liquidity ratio for Nordic banks was $46 \%$, while for non-Nordic banks it was 78\% for the period 2003-2016. Capital and liquidity ratios remain at high levels in Latvia. The average ratios are above the European average, liquidity ratio is even as twice as high. 
Liquidity risk proxy (Loan-To-Deposit Ratio) shows positive effect on bank's stability, that can be explained by very low amount of issued loans compared to attracted loan, for the period 2003-2016 median Loan-To-Deposit ratio was only $53 \%$. Median Loan-To-Deposit Ratio for Nordic banks was $156.13 \%$, whereas for non-Nordic banks it was only $44.50 \%$ from 2003-2016. That again can be explained by bigger amount of issued loans by Nordic-owned banks and that non-Nordic banks attracted higher amount of deposits. Financing of non-Nordic banks is largely made up of non-resident deposits, whereas resident deposits of the private non-financial sector and funding provided by parent banks constitute the most significant funding source for Nordic-owned banks. For instance, at the end of 2016 non-Nordic banks had $57 \%$ of total deposits, that can be explained by these banks business model.

Again, from bank's stability point of view, Nordic banks are more risky as their loan portfolio is bigger and amount of attracted deposits lower. Nevertheless, the situation is drastically changing, as banks oriented on non-residents are forced to change their business models and decrease amount of non-resident deposits to $5 \%$ of total deposits in the near future. As a result, at the of 2017 the Loan-To-Deposit Ratio for Nordic banks decreased to almost $100 \%$, while for another banks' group increased to $42 \%$.

\subsubsection{Bank profitability}

As profitability proxy we used ROE (Return on Equity). Median of ROE was $10.18 \%$ and $9.11 \%$ for Nordic and non-Nordic banks respectively during 2003-2016. Even both figures are similar for a time period of 14 years, there is significant difference in a shorter time interval. After the last financial global crises in 2008/2009 non-Nordic banks achieved a higher ROE because of more substantial net income from commissions and fees and trading income. Nordic-owned banks, in turn, had a more effective cost composition and smaller net loan loss provisions.

Both groups are characterised by significantly different profitability trends and main sources of profit. The main source of profit for Nordic-owned banks is providing loans and services to domestic customers. Thus, a gradual expansion of the domestic loan portfolio, an improvement in the credit worthiness of domestic customers as well as higher economic growth prospects all support the profitability of those banks. Overall profitability of Latvia's banks can be viewed as a good. Weighted average ROE of the banks was $14.3 \%$ in 2016, significantly higher than the EU average, as according to EBA data, the weighted average ROE of EU banks was $3.3 \%$ in the fourth quarter of 2016. (EBA, 2017)

Non-Nordic banks weren't important credit market players in Latvia so far, and the income of those banks is primarily dependent on providing services to non-residents. The business models and profits of those banks were significantly affected by the tightening of the AML/CTF requirements both in Latvia and abroad, closing of the US dollar correspondent accounts in the US for a part of the banks, as well as the weak growth reported in the home countries of their foreign customers. 
Summarising the profitability impact on bank's stability, Nordic-owned banks position in the future looks more stable.

\subsubsection{Bank efficiency}

As bank efficiency proxy we used Cost-To-Income ratio (CIR). Median of CIR was $34,80 \%$ for Nordic and $29.98 \%$ for non-Nordic banks during 2003-2016. Overall, the banks of both groups have improved their performance efficiency within the last five years, supporting a reduction of CIR from an average of $72 \%$ in 2010 to $45 \%$ in 2015. In 2016 CIR for both group increased to $49.8 \%$ and $50.5 \%$ respectively. Even, it remains better than the average CIR of the EU credit institutions which was $65.7 \%$ in 2016, the options to further improve cost efficiency are limited. Significant spending cuts and cost efficiency improvements were on Nordic-owned banks' agenda in the previous years and the cost-reduction opportunities of banks, are being gradually exhausted and so is the potential for using cost reductions as a means of sustaining profit. Moreover, the administrative expenses of non-Nordic banks are expected to grow because of the need to boost investment in information technologies and human resources associated with the tightening of the AML/CTF requirements, at the same time strengthening the sustainability of the banks.

Summarising the bank efficiency impact on bank's stability non-Nordic banks were more efficient than Nordic banks in the past, but in the future Nordic-owned banks perspective to remain low CIR is much better comparing with growing CIR for nonNordic banks.

\section{Summary of bank's stability measurement results}

Comparing measurement results of bank's stability by using econometric model independent variables, we received that Nordic-owned banks performance between 2003 to 2016 was better than non-Nordic-owned banks performance, even the difference wasn't big. Dividing the time interval to periods before the last financial crisis (2003-2008), during the crisis (2009-2010) and after the crisis (2011-2016), we got the same results, that Nordic-owned banks were more stable comparing to non-Nordic banks.

Table 6. Measurement results of bank's stability scores: Nordic versus non-Nordic

\begin{tabular}{|l|l|l|}
\hline Time intervals & Nordic-owned banks & Non-Nordic-owned banks \\
\hline $2003 / 2016$ & 2,594373426 & 2,267588472 \\
\hline $2003 / 2008$ & 3,6686468 & 3,446393902 \\
\hline $2009 / 2010$ & $-0,566867718$ & $-0,613548316$ \\
\hline $2011 / 2016$ & 2,165657304 & 1,796464428 \\
\hline
\end{tabular}

Also, Nordic-owned banks measured stability of banks is less fluctuating comparing to non-Nordic-owned banks, as minimal and maximal values were -1,420/5,612 and $-5,554 / 10,822$ respectively. 
Table 7. Z-Scores results: Nordic versus Non-Nordic

\begin{tabular}{|l|l|l|l|}
\hline & Average & Min & Max \\
\hline Nordic-owned banks & 2,71276619 & $-2,52759$ & 10,95731 \\
\hline $\begin{array}{l}\text { Non-Nordic owned } \\
\text { banks }\end{array}$ & 2,21134986 & $-5,8299$ & 14,20505 \\
\hline
\end{tabular}

The same results we received by calculating Z-Scores valuables, Nordic-owned banks were more stable in comparison with non-Nordic- owned banks.

\section{Conclusions, proposals, recommendations}

Banking sector is the backbone of financial structure of a country. The stability of banks is one of the most crucial elements of a country's economic development. Banks in Latvia can be classified into foreign (mainly Nordic) owned banks, which focus on servicing residents and dominate in the resident loans and deposits market and those which specialise in servicing non-residents, and which are mainly domestic private person-owned banks.

This study explores the main determinants of stability of banks by using Multivariate Regression analysis of banks operated in Latvia over the period 2003-2016. We found evidence that credit risk, liquidity risk, size, profitability, efficiency are the main bank-specific determinants of stability of banks in Latvia. The results also highlighted the significant role of inflation and GDP growth (macroeconomic variables) in explaining bank's stability. We made comparison of bank-specific variables performance for Nordic-owned and non-Nordic-owned banks. Credit and liquidity risks, as also efficiency ratio for Nordic-owned banks for analysed period were higher, whereas size of the banks and profitability were better. Comparing measurement results of stability of banks (stability scores and Z-Scores), we received that Nordic-owned banks performance between 2003 to 2016 was better than non-Nordic-owned banks performance.

Considering Latvia's GDP growth forecasts, the recovery of lending, the ability of banks to preserve quite high margins and boost their non-interest income, the overall profitability possibilities for Nordic-owned banks are expected to remain in high level. At the same time, less opportunities to continue with cutting the operating costs and to boost the income by raising the commissions and fees, shortcomings in the business environment and a relatively small pool of domestic customers as well as the exposure of the Latvian economy to external uncertainties, can lead to more modest profitability then in previous years. Moreover, banks have to pay an increasing attention to the growing competition from the non-bank financial sector in several areas of financial services. 
The authors expect that the business activities of non-Nordic banks will continue to decrease, and, at the same time, these banks will have to dedicate more resources to ensure the implementation of the high AML/CTF standards and safeguard their reputation. The significant decrease in banks' profits means that non-Nordic banks will have to reshape their business models, including also exit from market. The empirical findings have useful implications for the regulators and policy makers. Overall the results suggest that both bank-specific and macroeconomic variables are important for the stability of banking sector. For policy makers and bank management it will be useful to control those factors that can destabilize the banking sector.

\section{References:}

Adusei, M. 2015. The Impact of Bank Size and Funding Risk on Bank Stability. Economics and Finance, 3.

Buston, C.S. 2016. Active Risk Management and Banking Stability. Journal of Banking and Finance, 72. 203-215.

Carletti, K. 2007. Cross border banking and composition policy. European Central Bank Research Bulletin, 4, 7-10.

Claire, R.S. 2004. Macroeconomic Determinants of Banking Financial Performance and Resilience in Singapore. Monetary Authority of Singapore, Staff Paper No. 38. 134.

Curak, M., Poposki, K. and Pepur, S. 2012. Profitability Determinants of the Macedonian Banking Sector in Changing Environment. Journal of Social and Behavioural Sciences, 4, 406-416.

Diaconu, R.I. and Oanea, D.C. 2014. The Main Determinants of Bank's Stability: Evidence from Romanian Banking Sector. Journal of Economics and Finance, 16, 329-335.

Douglas W.D. and Raghuram G.R. 2005. Liquidity Shortages and Banking Crises. Journal of Finance, American Finance Association, 60(2), 615-647.

Fang, Y., Hasan, I. and Marton, K. 2010. Institutional development and bank stability: Evidence from transition countries. Journal of Banking and Finance, 39, 160-176.

Fell, J. and Schinasi, G. 2005. Assessing Financial Stability: Exploring the Boundaries of Analysis. National Institute Economic Review, 192(1), 102-117.

Financial Stability reports, Bank of Latvia, 2008-2017.

Ghenimi, A., Chaibi, H. and Omri, M.A.B. 2017. The effects of liquidity risk and credit risk on bank stability: Evidence from the MENA region. Borsa Istanbul Review, $\mathrm{XX}, 1-11$.

Imbierowicz, B. and Rauch, C. 2014. The relationship between liquidity risk and credit risk in banks. Journal of banking and finance, 40, 242-256.

Karim, N.A. 2016. Macroeconomic Indicators and Bank Stability: A Case of Banking in Indonesia. Buletin Ekonomi Moneter dan Perbankan, 18(4), 431-448.

Kisel, A.D. and Kisel, A.A. 2013. Analysis of Banking Business and its Impact on Financial Stability of Economies in Euro Area. Polish Journal of Management Studies, 8, 121-131.

Kohler, M. 2015. Which Banks are More Risky? The Impact of Business Models on Banks Stability. Journal of Financial Stability, 16, 195-212. 
Latvian banks financial reports from 2003 to 2016.

Madi, M.E.S. 2016. Determinants of financial stability in UK banks and building societies-Are they different? Journal of Business Studies Quarterly, 8(2), 78-89.

Mirzaei, A., Moore, T. and Liu, G. 2013. Does market structure matter on banks' profitability and stability? Emerging vs. advanced economies. Journal of Banking and Finance, 37, 2920-2937.

Mollah, S. and Zaman, M. 2015. Shari'ah supervision, corporate governance and performance: Conventional vs. Islamic banks. Journal of Banking and Finance, 58, 418-435.

Monnin, P. and Jokipii, T., 2010. The Impact of Banking Sector Stability on the Real Economy. Swiss National Bank Working Papers, ISSN 1660-7724, 1-31.

Nier, E.W. 2005. Bank Stability and Transparency. Journal of Financial Stability, 1, 342354.

Nikolaou, K. 2009. Liquidity (risk) concepts definitions and interactions. ECB Working paper series, No 1008, 72 .

OECD report. 2016. Latvia: review of the financial system European Banking Authority, 2017. Risk Assessment of the European Banking System, https://doi.org/10.2853/816166.

Perry, P. 1992. Do banks gain or lose from inflation. Journal of Retail Banking 14, 25-30.

Petria, N., Capraru, B. and Ihnatov, I. 2015. Determinants of banks' profitability: Evidence from EU 27 banking systems. Journal of Economics and Finance, 20, 518-524.

Rupeika-Apoga, R. and Danovi, A. 2015. Availability of Alternative Financial Resources for SMEs as a Critical Part of the Entrepreneurial Eco-System: Latvia and Italy. Procedia Economics and Finance, 33(15), 200-210, https://doi.org/10.1016/S22125671(15)01705-0.

Rupeika-Apoga, R. and Nedoviss, R. 2014. The Foreign Exchange Exposure of Baltic Non-financial Companies: Myth or Reality? In 8th International Days of Statistics and Economics, 1282-1292.

Shijaku, G. 2016. Banking Stability and its Determinants: A Sensitivity Analysis on Methodological Changes. Economic Review, 18-30.

Tan, Y. 2016. The impacts of risk and competition on bank profitability in China. Journal of International Financial Market, Institutions \& Money, 40, 85-110.

Thalassinos, I.E., Stamatopoulos, D.T. and Thalassinos, E.P. 2015. The European Sovereign Debt Crisis and the Role of Credit Swaps. Chapter book in The WSPC Handbook of Futures Markets (eds) W. T. Ziemba and A.G. Malliaris, in memory of Late Milton Miller (Nobel 1990) World Scientific Handbook in Financial Economic Series Vol. 5, Chapter 20, pp. 605-639, ISBN: 978-981-4566-91-9, (doi: 10.1142/9789814566926_0020).

Thalassinos, I.E., Hanias, P.M., Curtis, G.P. and Thalassinos, E.J. 2013. Forecasting financial indices: The Baltic Dry Indices. Marine Navigation and Safety of Sea Transportation: STCW, Maritime Education and Training (MET), Human Resources and Crew Manning, Maritime Policy, Logistics and Economic Matters; Code 97318, 283-290, ISBN: 978-113800104-6.

Thalassinos, I.E., Hanias, P.M. and Curtis, G.P. 2012. Time series prediction with neural networks for the Athens Stock Exchange indicator. European Research Studies Journal, 15(2), 23-31.

Titko, J., Kozlovskis, K. and Kaliyeva, G. 2015. Competition-Stability Relationship in the Banking Sector. Journal of Systemic, Cybernetics and Informatics, ISSN: 1690$4524,13(2), 25-31$. 
Bank Stability: The Case of Nordic and Non-Nordic Banks in Latvia 